\title{
PENGARUH MODEL PEMBELAJARAN LEARNING CYCLE BERBASIS EKSPERIMEN TERHADAP HASIL BELAJAR SISWA PADA MATERI POKOK ZAT DAN WUJUDNYA
}

\author{
Eva M. Ginting dan Harin Sundari \\ Jurusan Fisika, FMIPA Universitas Negeri Medan \\ Jl. Willem Iskandar, Psr V-Medan
}

\begin{abstract}
Abstrak. Penelitian ini bertujuan untuk menjelaskan pengaruh model pembelajaran learning cycle berbasis eksperimen terhadap hasil belajar siswa pada materi pokok zat dan wujudnya. Populasi dalam penelitian ini adalah seluruh siswa kelas VII semester I SMP Negeri 39 Medan Tahun Pelajaran 2011/2012 yang berjumlah 240 orang dan sampel diambil dari populasi sebanyak 2 kelas dengan menggunakan teknik cluster random sampling. Satu kelas sebagai kelas eksperimen yang diajar dengan Model Pembelajaran Learning Cycle yang berbasis eksperimen yaitu kelas VII-A dan satu kelas sebagai kelas kontrol yaitu kelas VII-F, kelas yang diajar dengan pembelajaran konvensional. Hasil penelitian menunjukkan nilai rata-rata pretes kelas eksperimen adalah 38,0 dan pada kelas kontrol 37,2. Setelah dilakukan perlakuan pada masing-masing kelas diperoleh nilai rata-rata postes pada kelas eksperimen sebesar 70,3 sedangkan pada kelas kontrol sebesar 61,2 . Pada hasil pengujian hipotesis dengan menggunakan uji $t$ dua pihak pada pretes diperoleh $-t_{\text {tabel }}<t_{\text {hitung }}<t_{\text {tabel }}(-1,9<0,27<1,9)$, didapat hasil bahwa antara kelas eksperimen dan kelas kontrol mempunyai kemampuan awal yang sama. Berdasarkan hasil pengujian hipotesis dengan menggunakan uji $\mathrm{t}$ satu pihak diperoleh $t_{\text {hitung }}>t_{\text {tabel }}(3,5>1,667)$, maka $\mathrm{H}_{\mathrm{o}}$ di tolak dan $\mathrm{H}_{a}$ di terima, ini berarti ada pengaruh menggunakan model pembelajaran Learning Cycle Berbasis Eksperimen terhadap hasil belajar siswa pada materi pokok Zat dan Wujudnya.
\end{abstract}

Kata kunci: model pembelajaran, learning cycle, eksperimen, hasil belajar

\section{Pendahuluan}

Pembelajaran adalah suatu proses dimana lingkungan seseorang secara disengaja dikelola untuk memungkinkan ia turut serta dalam tingkah laku tertentu dalam kondisi-kondisi khusus atau menghasilkan respons terhadap situasi tertentu. Pembelajaran mempunyai dua karakteristik yaitu pertama, dalam proses pembelajaran melibatkan proses mental siswa secara maksimal, bukan hanya menuntut siswa sekedar mendengar, mencatat, akan tetapi menghendaki aktivitas siswa dalam proses berfikir. Kedua, dalam pembelajaran membangun suasana dialogis dan proses tanya jawab terus menerus yang diarahkan untuk memperbaiki dan meningkatkan kemampuan berfikir siswa, yang pada gilirannya kemampuan itu dapat membantu siswa untuk memperoleh pengetahuan yang mereka konstruksi sendiri. (Sagala, 2009).

Hakikat IPA meliputi empat unsur, yaitu: (1) produk: berupa fakta, prinsip, teori, dan hukum; (2) proses: prosedur pemecahan masalah melalui metode ilmiah; metode ilmiah meliputi pengamatan, penyusunan hipotesis, perancangan eksperimen, percobaan atau penyelidikan, 
pengujian hipotesis melalui eksperimentasi; evaluasi, pengukuran, dan penarikan kesimpulan; (3) aplikasi: penerapan metode atau kerja ilmiah dan konsep IPA dalam kehidupan sehari-hari; (4) sikap: rasa ingin tahu tentang obyek, fenomena alam, makhluk hidup, serta hubungan sebab akibat yang menimbulkan masalah baru yang dapat dipecahkan melalui prosedur yang benar; sains bersifat open ended. (http://www.puskur.net/mdl/050 Model IPA Trpd.pdf).

Rendahnya nilai ujian siswa pada pelajaran Fisika disebabkan karena banyak diantara siswa yang menganggap Fisika itu sangat sulit, selain itu juga pembelajaran yang tidak menarik dan hanya monoton dengan menggunakan metode ceramah membuat siswa merasa jenuh dan bosan. Saat pembelajaran berlangsung, guru hanya sesekali melontarkan pertanyaan yang terkadang pertanyaan itu tidak bisa dijawab oleh siswa. Kebosanan dan kejenuhan siswa dapat dilihat dari banyaknya siswa yang tidak memperhatikan guru saat menerangkan, karena siswa lebih tertarik dengan hal-hal yang lain. Pembelajaran yang hanya menggunakan metode ceramah tersebut menyebabkan pembelajaran kurang aktif dan kurang efektif, sehingga menyebabkan hasil belajar siswa rendah baik pada ranah kognitif, afektif dan psikomotorik.

Selain itu, berdasarkan studi pendahuluan yang dilakukan oleh peneliti di SMP Negeri 39 Medan melalui pembagian agket kepada 37 orang siswa serta wawancara dengan guru mata pelajaran IPA, diperoleh data sebagai berikut:

1. Sebanyak $64,7 \%$ siswa tidak menyukai pelajaran Fisika dengan berbagai alasan, antara lain karena Fisika adalah pelajaran yang sulit dan banyak menggunakan rumusrumus. Hal ini menunjukkan bahwa pembelajaran kurang menyenangkan.

2. Sebanyak $73 \%$ siswa menyatakan bahwa proses belajar Fisika yang selama berlangsung di kelas mereka adalah mencatat dan mengerjakan soal, sedangkan sebanyak $40,5 \%$ siswa menginginkan proses belajar Fisika itu dengan menggunakan metode praktikum dan demonstrasi, $21,6 \%$ dengan mengerjakan soal, $18,9 \%$ dengan belajar sambil bermain. Hal ini menunjukkan bahwa proses pembelajaran Fisika kurang melatih siswa untuk aktif dan kreatif.

3. Hasil wawancara dengan guru menyatakan bahwa selama ini proses pembelajaran hanya menerapkan model konvensional saja serta terdapat beberapa kendala yang dihadapi oleh guru, diantaranya siswa pasif, siswa kurang konsentrasi, dan siswa lemah dalam menghitung.

4. Hasil wawancara dengan guru menyatakan bahwa banyak siswa yang melakukan remedial untuk pencapaian KKM. Hal ini menunjukkan bahwa pembelajaran kurang efektif.

Keterlibatan siswa secara aktif dalam proses pembelajaran mendukung siswa untuk membangun pengetahuannya sendiri, sehingga pembelajaran akan berpusat pada siswa (student centered) dan bukan pada guru (teacher centered). Menurut teori konstruktivisme, satu prinsip yang paling penting dalam psikologi pendidikan adalah bahwa guru tidak hanya sekedar memberikan pengetahuan kepada siswa. Siswa harus membangun sendiri pengetahuan didalam benaknya. Guru dapat memberikan kemudahan untuk proses ini dengan member kesempatan siswa untuk menemukan atau menerapkan ide-ide mereka sendiri dan mengajar siswa menjadi sadar dan secara sadar menggunakan strategi mereka sendiri untuk belajar (Trianto, 2009).

Proses pembelajaran konvensional yang disampaikan guru berupa metode ceramah, tanya jawab, dan diskusi. Dimana pada proses pembelajaran konvensional tujuannya adalah siswa mengetahui sesuatu bukan mampu untuk melakukan sesuatu, dan pada saat proses pembelajaran siswa lebih banyak mendengarkan. Disini terlihat bahwa pendekatan konvensional yang dimaksud adalah proses pembelajaran yang lebih banyak didominasi gurunya sebagai pen-transfer ilmu, sementara siswa lebih pasif sebagai penerima ilmu. Sehubungan dengan masalah diatas maka salah satu alternatif yang dipahami peneliti untuk mengatasi masalah di 
Ginting, E.M., dan Sundari, H.: Pengaruh Model Pembelajaran Learning Cycle Berbasis Eksperimen Terhadap Hasil Belajar Siswa Pada Materi Pokok Zat dan Wujudnya atas adalah dengan menggunakan model pembelajaran Learning Cycle (Siklus Belajar). Dengan menggunakan model pembelajaran Learning Cycle ini diharapkan mampu memecahkan permasalahan diatas sehingga siswa dapat berperan aktif, efektif dalam proses belajar mengajar.

Learning Cycle terdiri dari 5 tahap yaitu engage, explore, explain, elaborate dan evaluate. Pada tahap engagement (pembangkit minat) (Wena, 2009). Pada tahap ini, guru berusaha membangkitkan dan mengembangkan minat dan keingintahuan siswa tentang topik yang akan diajarkan. Hal ini dilakukan dengan cara mengajukan pertanyaan tentang proses faktual dalam kehidupan sehari-hari (yang berhubungan dengan topik bahasan). Pada tahap exploration (eksplorasi), siswa secara aktif berinteraksi dengan lingkungan melalui kegiatan-kegiatan seperti praktikum dan mengerjakan LKS. Pada tahap ini siswa diberikan kesempatan untuk melakukan eksperimen sehingga siswa berkesempatan untuk mengalami sendiri, mengikuti proses, mengamati suatu objek, menganalisis, membuktikan tentang suatu hukum atau persamaan. Pada tahap explanation (penjelasan), siswa dituntut untuk menjelaskan pengetahuan yang mereka peroleh dari tahap explore dengan kata-kata mereka sendiri, serta kreatif dalam mengembangkan gagasan pada saat diskusi. Pada tahap elaboration (elaborasi), siswa harus aktif untuk menerapkan pengetahuan tadi kedalam fenomena yang baru. Sedangkan pada tahap evaluation (evaluasi) dilakukan untuk menilai pengetahuan, pemahaman konsep yang telah dipelajarinya. Dengan melaksanakan kegiatan pembelajaran tersebut diharapkan tercipta pembelajaran yang efektif sehingga terdapat peningkatan pada hasil belajar siswa.

Selain itu dengan memfokuskan menggunakan metode eksperimen dalam pembelajaran Fisika, diharapkan guru dapat mengembangkan fisik atau mental, serta emosional siswa. Metode eksperimen adalah cara penyajian bahan pelajaran dimana siswa melakukan eksperimen (percobaan) dengan mengalami dan membuk- tikan sendiri sesuatu yang dipelajari. Dalam proses belajar mengajar dengan metode eksperimen, siswa diberi pengalaman untuk mengalami sendiri tentang suatu objek, menganalisis, membuktikan, dan menarik kesimpulan tentang suatu objek keadaan. Siswa mendapatkan kesempatan untuk melatih keterampilan proses agar memperoleh hasil belajar yang maksimal. Pengalaman yang diperoleh secara langsung dapat tertanam didalam ingatannya. Keterlibatan fisik dan mental serta emosional siswa dapat menumbuhkan rasa percaya diri dan juga perilaku yang inovatif dan kreatif. Berdasarkan uraian dari pendahuluan di atas maka penelitian ini dilakukan dengan mengangkat masalah tentang pengaruh model pembelajaran learning cycle berbasis eksperimen terhadap hasil belajar siswa pada materi pokok zat dan wujudnya.

\section{Metode Penelitian}

Penelitian ini dilaksanakan di SMP Negeri 39 Medan Kecamatan Medan Marelan dan waktu pelaksanaannya pada semester II Tahun Pelajaran 2012/2013. Populasi dalam penelitian ini adalah seluruh siswa kelas VII semester I SMP Negeri 39 Medan T.P 2011/ 2012 yang berjumlah 240 orang. Sampel diambil dari populasi yaitu sebanyak 2 kelas dengan teknik cluster random sampling. Satu kelas dijadikan sebagai kelas eksperimen yaitu kelas yang diajar dengan model pembelajaran Learning Cycle yang berbasis eksperimen yaitu kelas VII-A dan satu kelas lagi dijadikan sebagai kelas kontrol yaitu kelas VII-F, kelas yang diajar dengan pembelajaran konvensional.

Penelitian ini dilaksanakan dengan langkah-langkah sebagai berikut:

1. Tahap Persiapan

Penelitian ini meliputi konsultasi, membuat draft proposal penelitian, menyusun butir tes materi pokok Zat dan wujudnya.

2. Tahap Pelaksanaan:

- Menentukan kelas sampel dari populasi yang ada.

- Melaksanakan pretes kepada kedua kelas untuk mengetahui kemampuan awal siswa terhadap materi yang diajarkan. 
- Memberikan perlakuan kepada kedua kelas. Pada kelas eksperimen diberi perlakuan dengan model pembelajaran Learning Cycle yang berbasis eksperimen dan pada kelas kontrol diberi perlakuan dengan pembelajaran konvensional.

Pengujian hipotesis dilakukan dengan dua cara yaitu:

a. Uji kesamaan rata-rata pretest (uji t dua pihak) Uji t dua pihak digunakan untuk mengetahui kesamaan kemampuan awal siswa pada kedua kelompok sampel. Hipotesis yang diuji berbentuk:

$$
\begin{aligned}
& \mathrm{H}_{\mathrm{o}}: \mu_{1}=\mu_{2} \\
& \mathrm{H}_{\mathrm{a}}: \mu_{1} \neq \mu_{2}
\end{aligned}
$$

b. Uji kesamaan rata-rata postest (uji t satu pihak). Pengujian ada tidaknya pengaruh hasil postes siswa digunakan uji t satu pihak (pihak kanan) dengan hipotesis

$$
\begin{aligned}
& \mathrm{H}_{\mathrm{o}}: \mu_{1}=\mu_{2} \\
& \mathrm{H}_{\mathrm{a}}: \mu_{1}>\mu_{2}
\end{aligned}
$$

\section{Hasil Penelitian dan Pembahasan Hasil Penelitian}

Hasil penelitian yang dilakukan untuk mengetahui hasil belajar siswa sebelum kedua sampel diterapkan perlakuan yang berbeda, yaitu kelas eksperimen diberi perlakuan dengan menggunakan model pembelajaran Learning Cycle berbasis eksperimen dan kelas kontrol diberi perlakuan dengan menggunakan model pembelajaran konvensional, diperoleh data pretes kelas eksperimen dan kelas kontrol

\begin{tabular}{|c|c|c|c|c|c|c|c|}
\hline \multicolumn{4}{|c|}{ Kelas Eksperimen } & \multicolumn{4}{|c|}{ Kelas Kontrol } \\
\hline Nilai & Frek. & $\begin{array}{c}\text { Rata } \\
- \\
\text { rata }\end{array}$ & $\begin{array}{l}\text { Standar } \\
\text { Deviasi }\end{array}$ & Nilai & Frek. & $\begin{array}{c}\text { Rata } \\
- \\
\text { rata }\end{array}$ & Standar \\
\hline 6,7 & 2 & \multirow{10}{*}{38,0} & \multirow{10}{*}{14,0} & 6,7 & 1 & \multirow{10}{*}{37,2} & \multirow{10}{*}{13,3} \\
\hline 20,0 & 6 & & & 13,3 & 2 & & \\
\hline 26,7 & 3 & & & 20,0 & 2 & & \\
\hline 33,3 & 6 & & & 26,7 & 6 & & \\
\hline 40,0 & 6 & & & 33,3 & 9 & & \\
\hline 46,7 & 8 & & & 40,0 & 7 & & \\
\hline 53,3 & 7 & & & 46,7 & 8 & & \\
\hline \multirow[t]{3}{*}{60} & 2 & & & 53,3 & 1 & & \\
\hline & & & & 60,0 & 3 & & \\
\hline & & & & 66,7 & 1 & & \\
\hline 2 & $=40$ & & & & 40 & & \\
\hline
\end{tabular}
sebagai berikut.

Tabel 1. Data Pretes Kelas Eksperimen dan Kelas Kontrol
Setelah kedua sampel diterapkan perlakuan yang berbeda di mana pada kelas eksperimen diterapkan model pembelajaran Learning Cycle dan pada kelas kontrol diterapkan model pembelajaran konvensional diperoleh hasil

\begin{tabular}{|c|c|c|c|c|c|c|c|}
\hline \multicolumn{4}{|c|}{ Kelas Eksperimen } & \multicolumn{4}{|c|}{ Kelas Kontrol } \\
\hline Nilai & Frek. & $\begin{array}{c}\text { Rata } \\
- \\
\text { rata }\end{array}$ & $\begin{array}{l}\text { Standar } \\
\text { Deviasi }\end{array}$ & Nilai & Frek. & $\begin{array}{c}\text { Rata } \\
- \\
\text { rata }\end{array}$ & $\begin{array}{l}\text { Standar } \\
\text { Deviasi }\end{array}$ \\
\hline 53,3 & 3 & \multirow{8}{*}{70,3} & \multirow{8}{*}{9,8} & 40,0 & 4 & \multirow{8}{*}{61,2} & \multirow{8}{*}{13,6} \\
\hline 60,0 & 8 & & & 46,7 & 7 & & \\
\hline 66,7 & 8 & & & 53,3 & 5 & & \\
\hline 73,3 & 10 & & & 60,0 & 5 & & \\
\hline 80,0 & 8 & & & 66,7 & 7 & & \\
\hline 86,7 & 2 & & & 73,3 & 7 & & \\
\hline 93,3 & 1 & & & 80,0 & 3 & & \\
\hline & & & & 86,7 & 2 & & \\
\hline & $=40$ & & & & 0 & & \\
\hline
\end{tabular}
postes kedua kelas sebagai berikut.

Tabel 2. Data Postes Kelas Eksperimen dan Kelas Kontrol

Berdasarkan uji prasyarat diproleh data dari penelitian bahwa data tersebut normal dan hogomen. Untuk pengujian hipotesis dilakukan pengujian nilai pretes dengan menggunakan uji $\mathrm{t}$ dua pihak yaitu membedakan rata-rata pretes siswa kelas eksperimen dan kontrol dengan tujuan untuk melihat kemampuan awal siswa.. Hasil pengujian hipotesis pada $\alpha=0,05$ diperoleh harga $t_{\text {hitung }}=0,27$ dan $t_{\text {tabel }}=1,9$. Karena $-t_{\text {tabel }}<t_{\text {hitung }}<t_{\text {tabel }}(-1,9<0,27<1,9)$ dapat diperoleh kesimpulan bahwa antara kelas eksperimen dan kelas kontrol mempunyai kemampuan awal yang sama.

Hasil pengujian hipotesis dapat dilihat pada tabel berikut:

Tabel 3. Ringkasan Perhitungan Uji t Pada Pretes

\begin{tabular}{|c|c|c|c|c|c|}
\hline No. & Data Pretes & $\begin{array}{c}\text { Rata- } \\
\text { rata }\end{array}$ & $t_{\text {hitung }}$ & $t_{\text {tabel }}$ & Kesimpulan \\
\hline 1. & $\begin{array}{c}\text { Kelas } \\
\text { eksperimen }\end{array}$ & 38 & \multirow{2}{*}{0,27} & 1,9 & $\begin{array}{c}\text { Ada kesamaan } \\
\text { kemampuan } \\
\text { awal }\end{array}$ \\
\hline 2. & Kelas kontrol & 37,2 & & \\
\hline
\end{tabular}

Hasil pengujian hipotesis satu pihak pada postes dengan $\alpha=0,05$ diperoleh harga $t_{\text {hitung }}=$ 3,5 dan $t_{\text {tabel }}=1,667$. Dengan membandingkan $t_{\text {hitung }}$ dan $t_{\text {tabel }}$ diperoleh $t_{\text {hitung }}>t_{\text {tabel }}$ atau 3,5 $>$ 1,667 artinya Ho ditolak dan diterima Ha. Sehingga diperoleh kesimpulan bahwa hasil 
belajar siswa pada kelas eksperimen berbasis eksperimen lebih besar dibandingkan hasil belajar siswa pada kelas kontrol, maka pembelajaran Learning Cycle dikatakan berpengaruh terhadap hasil belajar siswa pada materi pokok Zat dan Wujudnya kelas VII SMP Negeri 39 Medan T.P 2012/2013.

Tabel 4. Ringkasan Perhitungan Uji t Pada Postes

\begin{tabular}{|c|c|c|c|c|c|}
\hline No. & $\begin{array}{l}\text { Data } \\
\text { Postes }\end{array}$ & $\begin{array}{c}\text { Rata- } \\
\text { rata }\end{array}$ & $t_{\text {hitung }}$ & $\mathrm{t}_{\text {tabel }}$ & Kesimpulan \\
\hline 1. & $\begin{array}{c}\text { Kelas } \\
\text { eksperimen }\end{array}$ & 70,3 & & & $\begin{array}{c}\text { Hasil belajar } \\
\text { dengan }\end{array}$ \\
\hline 2. & $\begin{array}{c}\text { Kelas } \\
\text { kontrol }\end{array}$ & 61,2 & 3,5 & 1,667 & $\begin{array}{c}\text { pembelajaran } \\
\text { Learning Cycle > } \\
\text { pembelajaran } \\
\text { Konvensional }\end{array}$ \\
\hline
\end{tabular}

Observasi ini dilakukan selama kegiatan belajar mengajar berlangsung oleh 2 orang pengamat yang telah dilengkapi dengan lembar observasi. Maka dapat dibuat rekapitulasi hasil observasi psikomotorik belajar siswa pada pertumuan I, II dan III seperti tercantum dalam Tabel 4 dibawah ini.

Tabel 5. Rekapitulasi Hasil Observasi Aktivitas Belajar Siswa

\begin{tabular}{|c|c|c|c|c|c|c|}
\hline \multirow[b]{2}{*}{ No } & \multirow[b]{2}{*}{ KELOMPOK } & \multicolumn{3}{|c|}{ Pertemuan } & \multirow{2}{*}{$\begin{array}{l}\text { Rata- } \\
\text { rata }\end{array}$} & \multirow[b]{2}{*}{ Nilai } \\
\hline & & I & II & III & & \\
\hline 1 & I & 8 & 9 & 12 & 9,7 & Cukup baik \\
\hline 2 & II & 12 & 11 & 14 & 12,3 & sangat baik \\
\hline 3 & III & 14 & 8 & 14 & 12 & sangat baik \\
\hline 4 & IV & 6 & 10 & 10 & 8,7 & Kurang baik \\
\hline 5 & $\mathrm{~V}$ & 8 & 8 & 12 & 9,3 & Cukup baik \\
\hline 6 & VI & 10 & 10 & 12 & 10,7 & Baik \\
\hline 7 & VII & 7 & 13 & 10 & 10 & Cukup baik \\
\hline 8 & VIII & 6 & 8 & 10 & 8 & Kurang baik \\
\hline & $\begin{array}{l}\text { RATA-RATA } \\
\text { PSIKOMOTORIK }\end{array}$ & & & & 10,1 & Cukup baik \\
\hline
\end{tabular}

Berdasarkan data pada Tabel 4, maka hasil observasi aktivitas belajar siswa selama menerapkan model pembelajaran Learning Cycle berbasis eksperimen menunjukkan bahwa ratarata skor aktivitas psikomotorik siswa pada ketiga pertemuan mencapai skor 10,1 dengan kategori nilai keaktifan siswa yang cukup baik.

\section{Pembahasan}

Penelitian ini dilakukan di kelas VII pada dua kelas yang diberikan perlakuan yang berbeda, dimana kelas kontrol diberikan pembelajaran Konvensional dan pada kelas eksperimen diberikan pembelajaran Learning
Cycle berbasis eksperimen pada materi pokok Zat dan Wujudnya SMP Negeri 39 Medan. Pada awal penelitian masing-masing kelas diberikan pretes untuk mengetahui kemampuan awal siswa pada materi pokok zat dan wujudnya. Hasil pretes diperoleh hasil belajar siswa pada kelas kontrol yaitu dengan rata-rata 37,2 dan pada kelas eksperimen dengan ratarata 38,0. Hasil pretes di atas menunjukkan bahwa kedua kelas memiliki kemampuan awal yang hampir sama karena hannya terpaut sedikit saja pada rata-rata nilai kedua kelas. Langkah selanjutnya peneliti melakukan perlakuan yang berbeda pada masing-masing kelas selama 3 kali pertemuan. Setelah diberikan perlakuan kemudian diadakan postes untuk mengetahui hasil belajar siswa. Hasil postes diperoleh nilai siswa pada kelas kontrol dengan rata-rata 61,2 dan pada kelas eksperimen 70,3 .

Berdasarkan hasil tersebut menunjukkan bahwa rata-rata hasil belajar siswa pada materi zat dan wujudnya di kelas VII setelah diberi pembelajaran dengan model pembelajaran Learning Cycle berbasis eksperimen lebih tinggi dibandingkan hasil belajar siswa yang diberikan pembelajaran dengan pendekatan konvensional. Hal ini memberikan makna bahwa ada pengaruh yang diberikan oleh pembelajaran dengan model pembelajaran learning cycle berbasis eksperimen terhadap hasil belajar siswa. Langkah selanjutnya yang diambil untuk membuktikan apakah benar-benar ada pengaruh yang signifikan secara statistik, maka dilakukan pengujian terhadap hipotesis. Hasil pengujian $t_{\text {hitung }}>t_{\text {tabel }}(3,5>$ 1,667), pada taraf signifikansi $\alpha=0,05 \mathrm{dan} d \mathrm{dk}$ $=78$. Adanya pengaruh yang diberikan oleh pembelajaran dengan model pembelajaran learning cycle berbasis eksperimen terhadap hasil belajar siswa di kelas VII pada materi pokok Zat dan Wujudnya di semester I SMPN 39 Medan secara statistik teruji kebenarannya berdasarkan hasil yang diperoleh.

Selain itu juga pretes dan postes yang dilakukan di kelas kontrol dan kelas eksperimen juga menunjukkan bahwa ada 7 soal dengan kategori mudah, 15 soal dengan kategori sedang, 
Ginting, E.M., dan Sundari, H.: Pengaruh Model Pembelajaran Learning Cycle Berbasis Eksperimen Terhadap Hasil Belajar Siswa Pada Materi Pokok Zat dan Wujudnya

3 soal dengan kategori sukar berdasarkan taraf kesukaran tes, hampir seluruh siswa mendapatkan skor yang sedikit pada soal tersebut. Hal ini disebabkan karena kurang percaya dirinya siswa dalam menjawab soal model pembelajaran ini mengembangkan pembelajaran secara berkelompok yaitu dengan metode eksperimen agar masing-masing siswa dapat saling menemukan sendiri pengetahuan itu, bertukar pikiran, berdiskusi dan bekerja sama dalam melakukan eksperimen. Pembelajaran dengan model learning cycle berbasis eksperimen ini lebih meningkatkan aktivitas psikomotorik siswa yang dapat dilihat rata-rata nilai aktivitas siwa sebesar 10,1 dengan interpretasi cukup baik.

Pembelajaran ini memiliki kelemahan dimana: 1) kondisi kelas dengan pembelajaran Learning Cycle sangat sulit dikontrol dan mudah riuh sebab dengan melakukan praktikum memberikan kesempatan kepada siswa untuk ribut, 2) alokasi waktu yang sangat sulit diatur karena dalam melakukan praktikum memerlukan alokasi waktu yang lebih banyak untuk pencapaian hasil yang lebih maksimal, 3) siswa kurang percaya diri dengan kemampuan yang dimilikinya, 4) dalam proses belajar mengajar siswa belum begitu percaya diri dengan pengetahuan yang ditemukannya sendiri, sehingga siswa cenderung bertanya pada guru. Hal ini disebabkan siswa sudah terbiasa dengan pembelajaran konvensional, dimana guru merupakan sumber utama dari pengetahuan yang didapat siswa.

Kelas yang diberikan pendekatan konvensional, siswa lebih banyak mendengarkan penjelasan guru didepan kelas, mencatat pelajaran dan kegiatan belajar mengajar berpusat pada guru. Kondisi ini mengakibatkan hanya sedikit siswa yang aktif dalam proses pembelajaran dan siswa menjadi kurang bersemangat. Inilah yang mempengaruhi kemampuan siswa yang terlihat dari hasil belajar Fisika yang masih tergolong rendah. Dengan demikian berdasarkan hasil penelitian yang dilakukan di
SMP Negeri 39 Medan pada siswa kelas VII pada materi zat dan wujudnya terbukti bahwa pembelajaran dengan model pembelajaran learning cycle berbasis eksperimen memberikan pengaruh terhadap hasil belajar siswa.

\section{Simpulan}

Berdasarkan hasil analisis data dan pengujian hipotesis maka dapat disimpulkan:

1. Rata-rata hasil belajar siswa pada kelas kontrol yang diberi perlakuan dengan pembelajaran konvensional adalah 61,2.

2. Rata-rata hasil belajar siswa pada kelas eksperimen yang diberi perlakuan dengan model pembelajaran Learning Cycle berbasis eksperimen adalah 70,3.

3. Ada pengaruh hasil belajar siswa yang signifikan antara kelompok siswa yang diajarkan dengan pembelajaran Learning Cycle dan pembelajaran konvensional pada pokok bahasan Tekanan, karena $t_{\text {hitung }}>$ $t_{\text {tabel }}(3,5>1,667)$, maka $\mathrm{H}_{\mathrm{o}}$ di tolak dan $\mathrm{H}_{a}$ di terima, dengan kata lain bahwa model pembelajaran Learning Cycle berbasis eksperimen lebih berpengaruh dari pada model pembelajaran Konvensional dalam meningkatkan hasil belajar siswa dengan besar peningkatan $14,8 \%$.

\section{Daftar Pustaka}

Sagala, S. 2008. Konsep dan Makna Pembelajaran. Bandung: Alfabeta.

Sudjana. 2005. Metoda Statistika. Bandung: Penerbit Tarsito.

Trianto. 2009. Mendesain Model Pembelajaran Inovatif-Progresif: Konsep Landasan, dan Impelementasinya Pada Kurikulum Tingkat Satuan Pendidikan (KTSP). Jakarta: Kencana Prenada Media Group.

Wena, M. 2009. Strategi Pembelajaran Inovatif Kontemporer; Suatu Tinjauan Konseptual Operasional. Jakarta: Bumi Aksara. 